\title{
HYDRODYNAMIC 2D MODEL OF THE CITY CENTRE HYDROSYSTEM OF THE CITY OF WROC ŁAW AND ITS FLOOD CAPACITY ANALYSIS
}

\author{
Robert Banasiak ${ }^{\bowtie}$ \\ Institute of Meteorology and Water Management, National Research Institute, ul. Parkowa 30, 051-616 Wrocław
}

\begin{abstract}
Aim of the study

Analysis of flood water flow through the Wrocław City Centre Hydrosystem before and after its modernisation.

Material and methods

Use of the MIKE21 numerical 2D hydrodynamic model supported by GIS tools. Use of historical floods hydrometrical data.
\end{abstract}

\begin{abstract}
Results and conclusions
Chosen hydraulic characteristics were presented, including the distribution of water flow in channels of the hydrosystem and water table profiles for both variants with an evaluation of the investment's influence. Maximum flow in the city section of the Odra river during the 1997 flood was verified.
\end{abstract}

Keywords: Odra river, City Centre Hydrosystem, two-dimensional hydrodynamic model, flood

\section{INTRODUCTION}

Wrocław City Centre Hydrosystem (CCH) includes the oldest, central part of the city (Fig. 1). It is a central part of the Wrocław's anti-flood system and it is responsible for a transfer of nearly one third of high flood waters. The rest of the flood waters flow around the city centre through the Flood Canal, the Old Odra and the Widawa river valley. This system and the Oławka and Blizanowice-Trestno detention basins constitute the Wrocław Hydrosystem (WH). Volume of the waters directed to the city centre depends on the distribution of waters in the Bartoszowicko-Opatowicki node, steering of the Oławka detention basin, and the Szczytniki system where the Old Odra branches off from the city section of Odra. Below the Szczytniki node there are the Grunwaldzki bridge, the Pokoju bridge and two relatively narrow distributaries of Odra, and namely the Southern and the Northern Odra. They, in turn, are divided into separate channels creating islands connected together with bridges with water constructions constituting the so-called upper checkdam with the Macieja weir, Maria mill, Klary channel (before with a mill) and Klary weir. Then, both distributaries of Odra converge and split again around the Uniwersyteckie bridges. Here, on the Southern Odra, the Wrocław I power plant with a weir (after a reconstruction) is located, and on the Northern Odra there is the Wrocław II power plant, also with a weir. These building constitute the so-called lower checkdam which is continuously used for electricity production. Odra converges below the Sikorskiego bridges (at $254.2 \mathrm{~km}$ ) to eventually join the Old Odra $(255.8 \mathrm{~km})$.

The $\mathrm{CCH}$ was a subject of numerous research and hydraulic analyses since as soon as the 1970s (Parzonka and Szczegielniak, 1972). Then, it was analysed within the works on creating the Guidelines on protection from floods in the Wrocław Province (WKP [Provin-

『e-mail: robert.banasiak@imgw.pl 


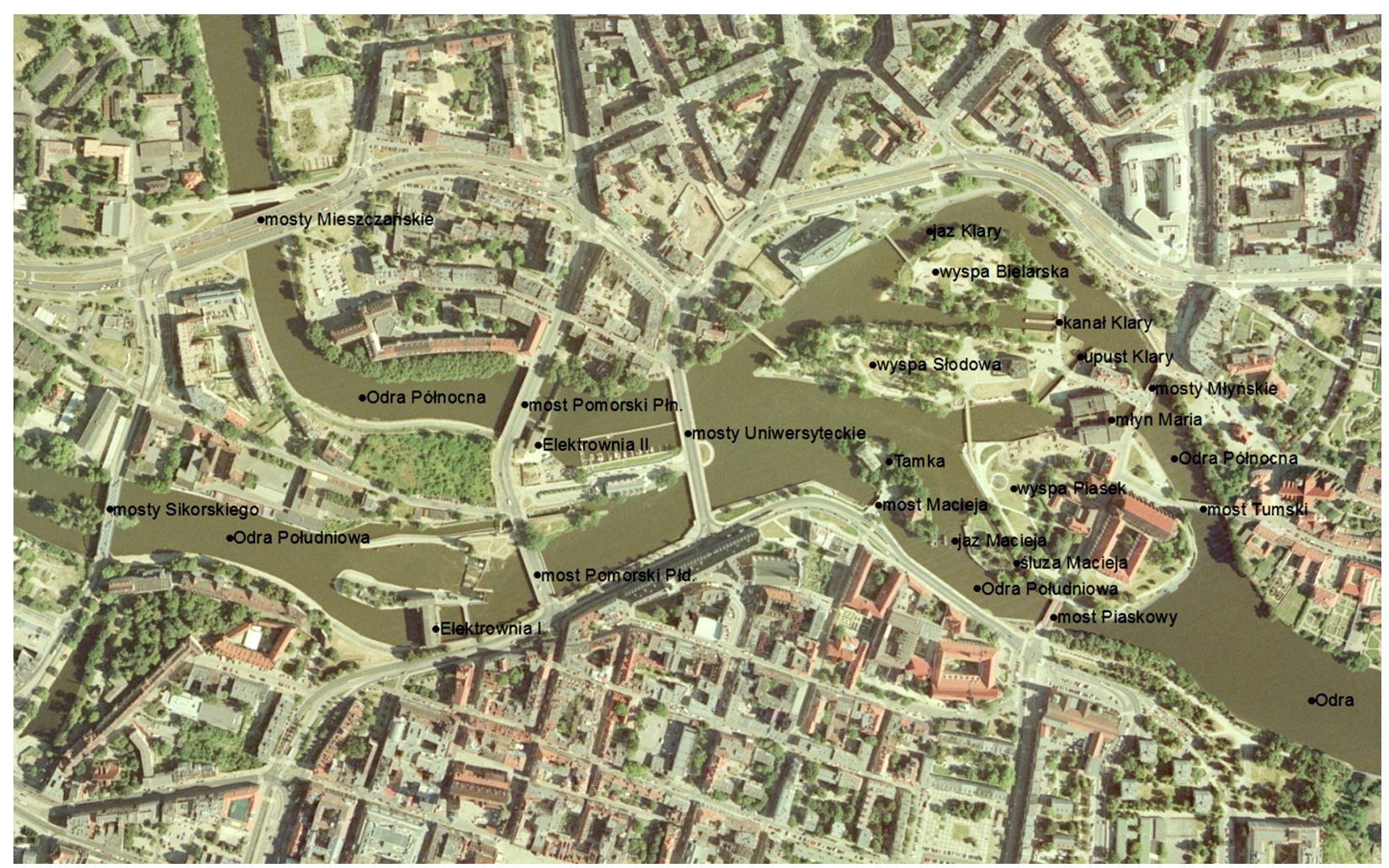

Fig. 1. Hydrosystem of the Wrocław city centre

cial Anti-flood Committee], 1993). The research intensified as a result of the catastrophic 1997 flood. Already during the passing of the flood wave, water level observations in numerous characteristic points of the $\mathrm{WH}$ had been quickly planned and conducted. Also, measurements of the flow rate in selected sections had been carried out allowing to sum up the total flow (Czaban, 1998). Further, the flow in the CCH was modelled numerically. The first attempt to do that was with a model based on the one-dimensional Saint-Venant equations (Kudela and Szczegielniak, 1994). Radczuk et al. (1999) presented a one-dimensional SiReN model, also based on the Saint-Venant equations, which was used to calculate flood waters distribution in the WH. Later, Jełowicki (1999) presented his numerical model for the $\mathrm{CCH}$ based on a solution combining a one-dimensional representation of beds and a two-dimensional representation of their connections using a finite volumes grid. Also, Czaban (1999) and, again, Radczuk et al. (2002) performed the capacity evaluation of the $\mathrm{WH}$ based on calculations using Manning's equation. Next stage was to prepare the modernisation of the WH. Within the framework of project preparation hydraulic calculations have been based on Szczegielniak's one-dimensional model (Hydroprojekt, 2004) and the Odra Basin Anti-flood Protection Project (Pol. PODPO) is its continuation. One of its goals was to formulate a numerical hydraulic model for the Wrocław Protection System (supervising unit: Regional Water Management Board in Wrocław). In 2012-2013, a one-dimensional model was created with MIKE11 software. It covered a section of Odra between $191.5 \mathrm{~km}$ (above Brzeg town) and $284.7 \mathrm{~km}$ (Brzeg Dolny town). The model covers all critical elements of the $\mathrm{WH}$, including the $\mathrm{CCH}$, and it was calibrated based on data from 2010 flood. Also, a version of this model including planned investments was created.

It is worth mentioning that at the Wrocław University of Environmental and Life Sciences a large size physical design (17 $\mathrm{m}$ long and $6.5 \mathrm{~m}$ wide; 1:200 scale) of the $\mathrm{CCH}$ was created, and it is supposed to serve to perform hydraulic analyses of the system (Tymiński, 2011). 
Within the framework of implementation of the Country Protection IT System against extraordinary threats (Pol. ISOK) two-dimensional (2D) models with $5 \times 5 \mathrm{~m}^{2}$ calculation grid resolution for the city of Wrocław were created. They were used to determine maps of flood hazard and risk (ISOK, 2013). These models were further developed and calibrated more precisely based on hydrometric measurements of the 2010 flood (Banasiak, 2017). Another model presented in this study is a two-dimensional high-resolution model that enables detailed study of hydraulic conditions of flood waters passing in the complicated system of channels and hydraulic structures of the $\mathrm{CCH}$. The aim of creating the model and performing the analyses is to verify, complement and detail earlier flood capacity data of the $\mathrm{CCH}$ using new possibilities of numerical simulations that improve calculations credibility and accuracy.
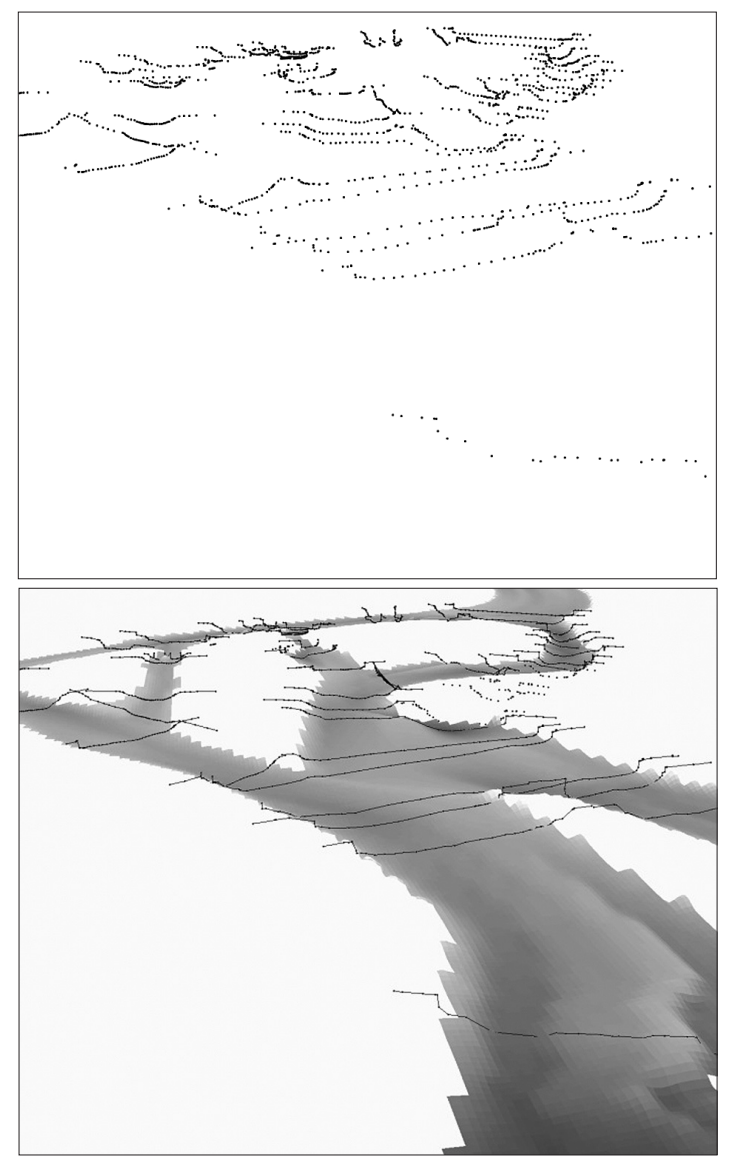

Fig. 2. Generating the bathymetry model: a) channel survey points; b) linear interpolation; c) conversion to

a raster; d) after merging with the digital terrain model (DTM)

\section{DESCRIPTION OF THE MODEL}

The hydrodynamic model was realised with MIKE21 platform of the Danish Hydraulic Institute (DHI). A principal element of the model is a geometrical representation of a modelled object, i.e. computational bathymetry. It is based on bed sections measured in 2012 as well as a digital terrain model (DTM) that was also acquired in 2012 within the ISOK project with airborne laser scanning in the 2nd standard (for cities) of a point cloud with the following parameters: density $12 \mathrm{p} / \mathrm{m}^{2}$, average vertical position error of $0.10 \mathrm{~m}$, average horizontal position error of $0.4 \mathrm{~m}$. Computational bathymetry was created as a result of the following procedure: 1) Generating a bed bathymetry based on bed sections using linear interpolation and combining it with the DTM in ArcGIS environment (see: Fig. 2); 2) Introducing buildings and hy-
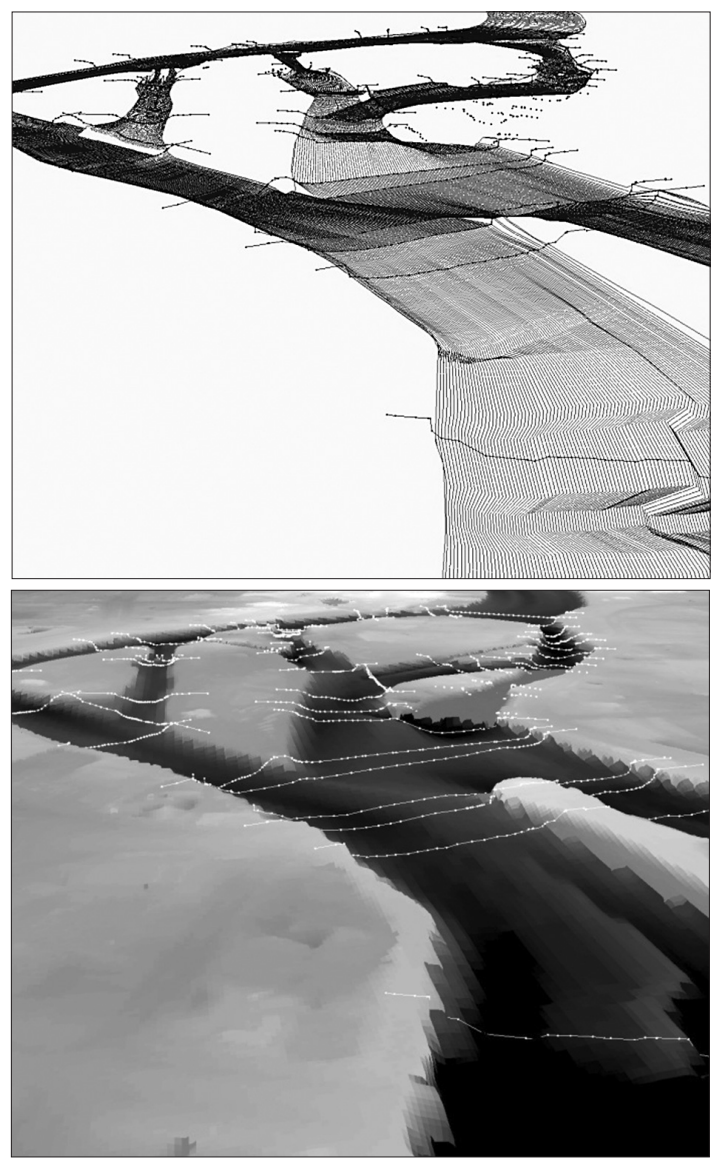
drotechnical constructions by adjusting the ordinates of the respective calculation cells; 3 ) Introducing boundary conditions (external borders and the socalled entry and exit basins).

Computational bathymetry (see: Fig. 3) covers the section of Odra from the Pokoju bridge to a rail bridge below the connection of the Northern and Southern Odra. A bathymetry of $1 \times 1 \mathrm{~m}^{2}$ resolution (an orthogonal calculation grid) has the size of $2400 \times 1750$ elements, which results in total of 4.2 mil points. Such a resolution allows for a good geometric representation of the channels and structures of the $\mathrm{CCH}$. A certain difficulty in the creation of the computational bathymetry was that it was based on cross-sections measured sometimes at considerable distances that do not fully capture the variability of the bed shape. This required some manual adjustments to the interpolated bathymetry. A comprehensive sounding / acoustic scanning would provide better bathymetric data base. Nevertheless, in conditions of the analysed high flows and high water depths, the impact of the local inaccuracies of the bed bathymetry loses significance.

\section{THE 2010 FLOOD AND THE CALIBRATION OF THE MODEL}

The calibration of the model in terms of high waters was performed based on the data from 2010 flood event. It was a large flood of a maximum flow of $2200 \mathrm{~m}^{3} \cdot \mathrm{s}^{-1}$ at the entry to the WH. This means that this flood has a chance of occurring once in nearly a hundred years (recurrence probability nearly 1 per cent). Passing of the flood through the WH was relatively well-documented. Numerous flow rate measurements (using an ADCP and traditional current meters from bridges) as well as maximum level of water table records were done. Measurements also covered the $\mathrm{CCH}$, in which the flow ratio during the culmination of the wave was measured from

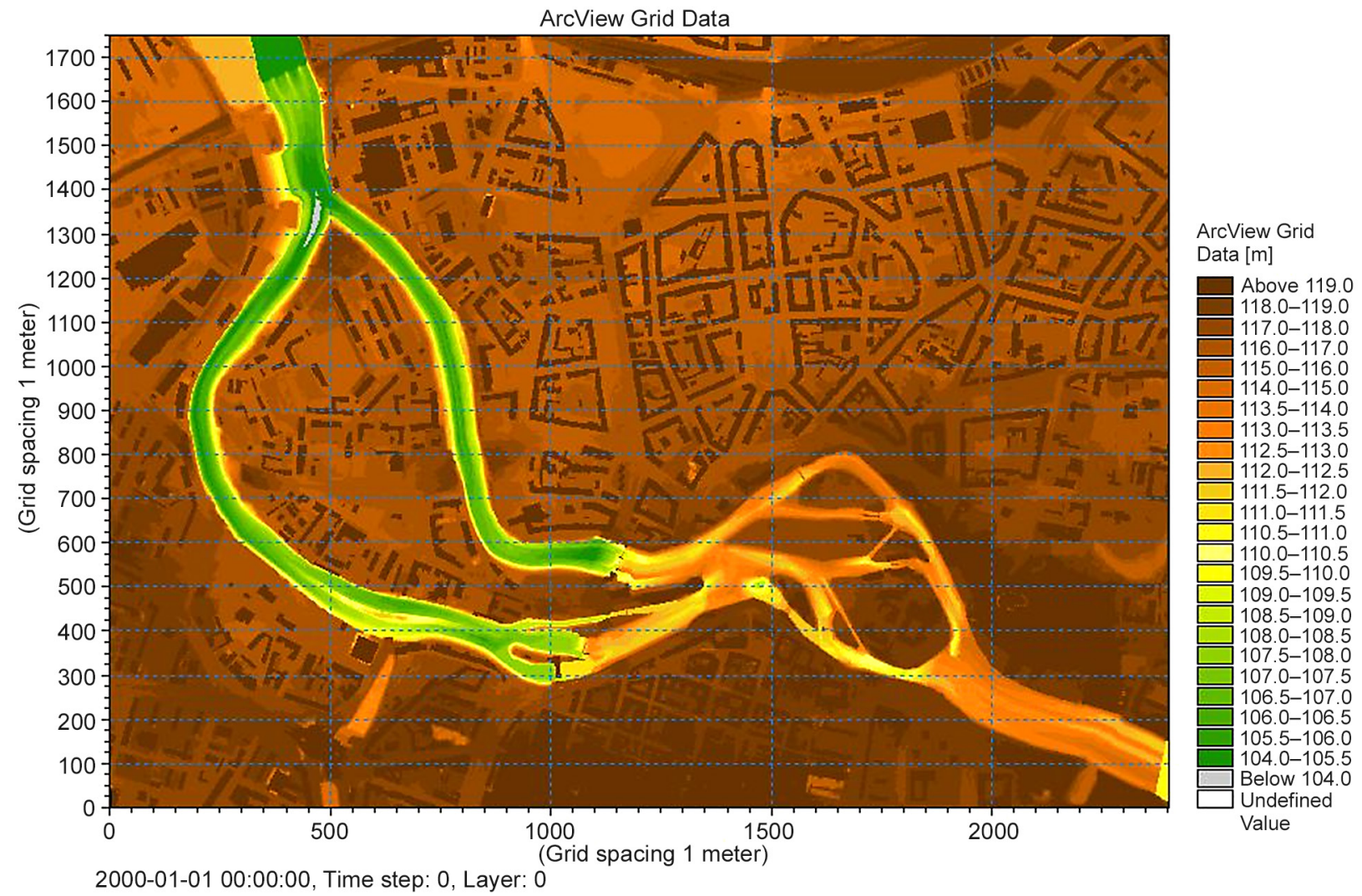

Fig. 3. Bathymetry of the 2D model 
the Pokoju bridge $\left(716 \mathrm{~m}^{3} \cdot \mathrm{s}^{-1}\right)$ and Sikorski and Mieszczański bridges (total of $729 \mathrm{~m}^{3} \cdot \mathrm{s}^{-1}$ ). Then, distribution of flows in the $\mathrm{WH}$ was verified iteratively using the 2D numerical model and the flow rate in the $\mathrm{CCH}$ reached a maximum of $740 \mathrm{~m}^{3} \cdot \mathrm{s}^{-1}$ (Banasiak, 2017). Consequently, this value was used to calibrate the presented model as an upper boundary condition in steady flow simulation, which is an appropriate solution for this relatively short section of Odra (unsteadiness effect is negligible). Results of calculations and measurements give good compatibility when it comes to flow distribution between the Northern and the Southern Odra below the Wrocław I checkdam (see: Table 1). The water table location was also taken into account within the calibration. In the Fig. 4 a raster of the highest calculated level of the water table, and the location of the measurement points and measured ordinates is presented. Compatibility of the simulation and observation results is within the range from a few to a dozen or so centimetres, which may be considered to be very good or good. It is worth noting that for the Odra bed and its channels a uniform value of the flow velocity coefficient (the inverse of the Manning's coefficient) was adopted, i.e. $36 \mathrm{~m}^{1 / 3} \cdot \mathrm{s}^{-1}$ in reference to earlier studies (Banasiak and Krzyżanowski, 2015). In this densely built-up system, where backwater and water damming effects occur, the correct representation of the geometry of the channels and constructions played a key role, while the impact of possible changes in the flow velocity coefficient is relatively small.

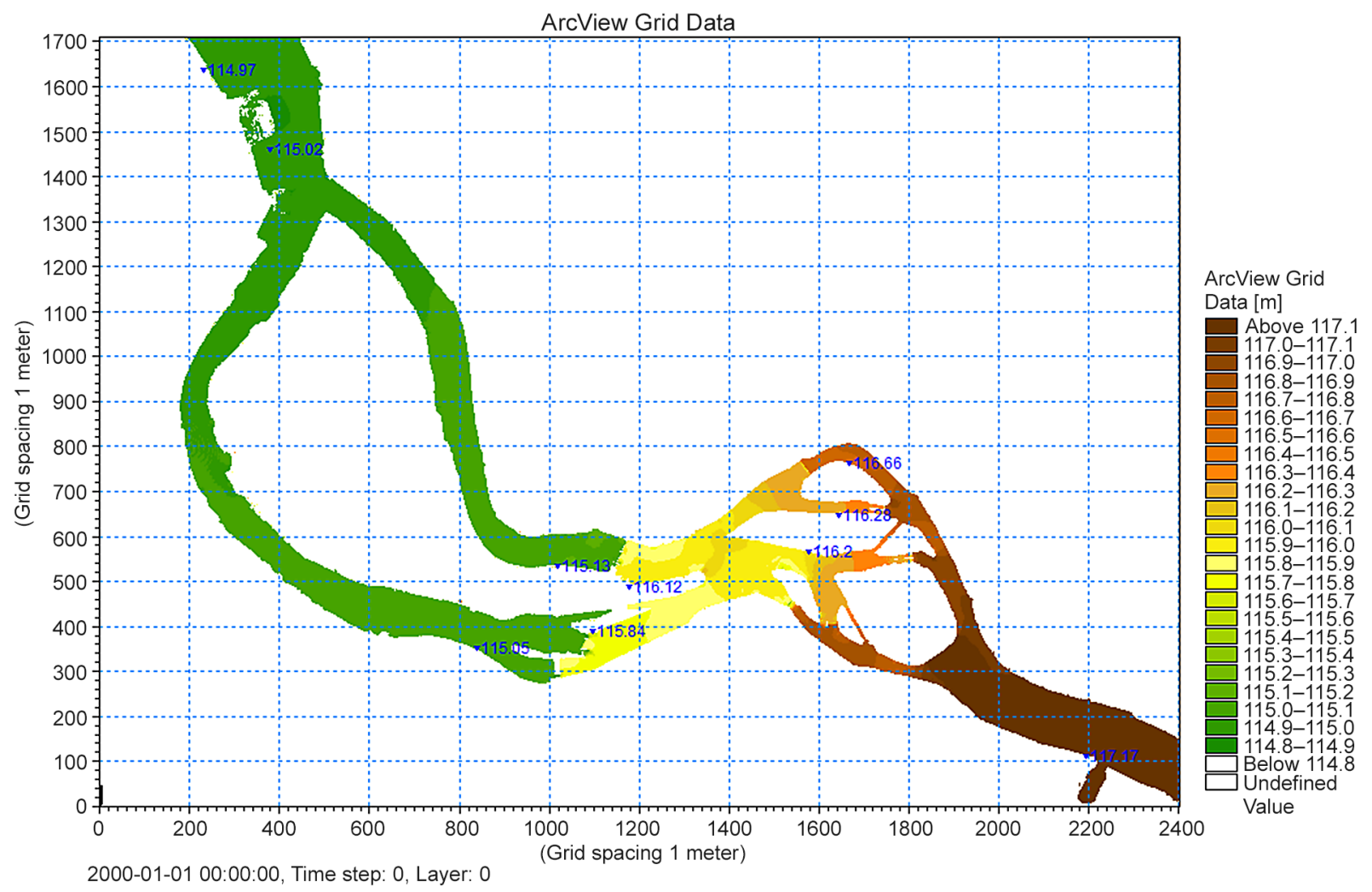

Fig. 4. Calculated and measured water level for the 2010 flood 
Table 1. Maximum flow distribution in the Wrocław Hydrosystem during the May 2010 flood, and before and after modernisation

\begin{tabular}{lcccc}
\hline \multicolumn{1}{c}{ Cross-section } & $\begin{array}{c}2010 \\
\text { Measure- } \\
\text { ment }\end{array}$ & $\begin{array}{c}2010 \\
\text { 2D } \\
\text { model }\end{array}$ & $\begin{array}{c}Q_{k} \\
\text { After } \\
\text { mod. }\end{array}$ & $\begin{array}{c}Q_{k} \\
\text { After } \\
\text { mod. }\end{array}$ \\
\hline $\begin{array}{l}\text { Pokoju bridge } \\
\text { (city section of Odra) }\end{array}$ & 716 & 740 & 984 & 909 \\
\hline $\begin{array}{l}\text { Piaskowy bridge } \\
\text { (the Southern Odra) }\end{array}$ & - & 402 & 525 & 488 \\
\hline Macieja bridge & - & 140 & 182 & 164 \\
\hline Macieja weir & - & 236 & 317 & 293 \\
\hline Macieja sluice & - & 26 & 27 & 34 \\
\hline $\begin{array}{l}\text { Tumski bridge } \\
\text { the Northern Odra) }\end{array}$ & - & 338 & 458 & 421 \\
\hline Maria mill & - & 92 & 127 & 113 \\
\hline Upust Klary channel & - & 31.5 & 34 & 40 \\
\hline Klary channel & - & 77.5 & 92 & 92 \\
\hline Klary weir & - & 137 & 205 & 176 \\
\hline $\begin{array}{l}\text { Sikorskiego bridge } \\
\text { (the Southern Odra) }\end{array}$ & 316 & 325 & 430 & 477 \\
\hline $\begin{array}{l}\text { Mieszczańskie } \\
\text { bridges } \\
\text { (the Northern Odra) }\end{array}$ & 413 & 415 & 554 & 432 \\
\hline
\end{tabular}

\section{CAPACITY BEFORE AND AFTER THE MODERNISATION}

The calibrated model was used to simulate the control flood water passage according to the assumptions adopted within the WH modernisation study (Hydroprojekt, 2004). In this study, the control flood for the WH was set to a value of $3100 \mathrm{~m}^{3} \cdot \mathrm{s}^{-1}$ (taking into account the Racibórz reservoir effect far upstream). From a simulation with a separate $2 \mathrm{D}$ model for the $\mathrm{WH}$, it was calculated that in this scenario the inflow into the $\mathrm{CCH}$ will be $984 \mathrm{~m}^{3} \cdot \mathrm{s}^{-1}$, whereby the opening of all closures of control hydrotechnical structures was assumed. However, in the scenario of implementing modernisation investments causing increase in water flow to the Widawa valley through the Odra-Widawa channel from 135 to $300 \mathrm{~m}^{3} \cdot \mathrm{s}^{-1}$, a control water flow of $909 \mathrm{~m}^{3} \cdot \mathrm{s}^{-1}$ will be directed to the $\mathrm{CCH}$ (Banasiak, 2018).
Modernisation works within the $\mathrm{CCH}$ include mainly modernisation of the embankments and boulevards of Odra and reconstruction of the weir at the Wrocław I power plant. The reconstruction consists in replacing a fixed weir with a gate weir (two spans with a width of $22 \mathrm{~m}$ each) with an ordinate of the weir crest at $112.48 \mathrm{~m}$ above sea level.

As a result of the performed simulations, it can be concluded that due to modernisation investments within the $\mathrm{CCH}$, the control water table will significantly decrease. This has been illustrated by the water table profiles in Fig. 5. Above the section where the bed divides into the Northern and Southern Odra, the decrease will amount to $0.25-0.3 \mathrm{~m}$, while below the lower checkdam to $0.7 \mathrm{~m}$. This is due to the above-mentioned inflow reduction, but also to the conveyance improvement of the Odra below, which decreases the water table being the lower boundary condition in the current model. The reconstruction of the Wrocław I weir has a limited effect on improving the flow conditions. It will reduce the water damming level, but mainly locally, reaching only to the upper checkdam. The reconstruction of the weir will, however, even out the flows between the Northern and the Southern Odra below this level. In Tab. 3 the distribution of flows in individual channels of the system was specified both before and after the modernisation.

The results confirm, therefore, an important finding of the study (Hydroprojekt, 2004), and namely, that the capacity of the city section of Odra is basically determined by the hydraulic conditions of the upper checkdam, which has a clearly smaller area of the active section compared to the lower checkdam. As a result of the decrease of the lower water position after the modernisation, the situation will deteriorate in the sense that the damming at the upper checkdam will increase (the difference between the level of the upper and lower water) and the local flow velocities will increase. As can be seen in Fig. 6, depth-averaged flow velocities will be $4 \mathrm{~m} \cdot \mathrm{s}^{-1}$. These velocities demonstrate the so-called "bottlenecks" of the system. These include the section of the Piaskowy and Młyński bridges (including the Maria mill) and the Macieja bridge and the Macieja weir.

The obtained results can be related to historical floods. After the modernisation, the location of the 
Banasiak, R. (2019). Hydrodynamic 2D model of the City Centre Hydrosystem of the city of Wroctaw and its flood capacity analysis. Acta Sci. Pol., Formatio Circumiectus, 18 (2), 3-12. DOI: http://dx.doi.org/10.15576/ASP.FC/2019.18.2.3

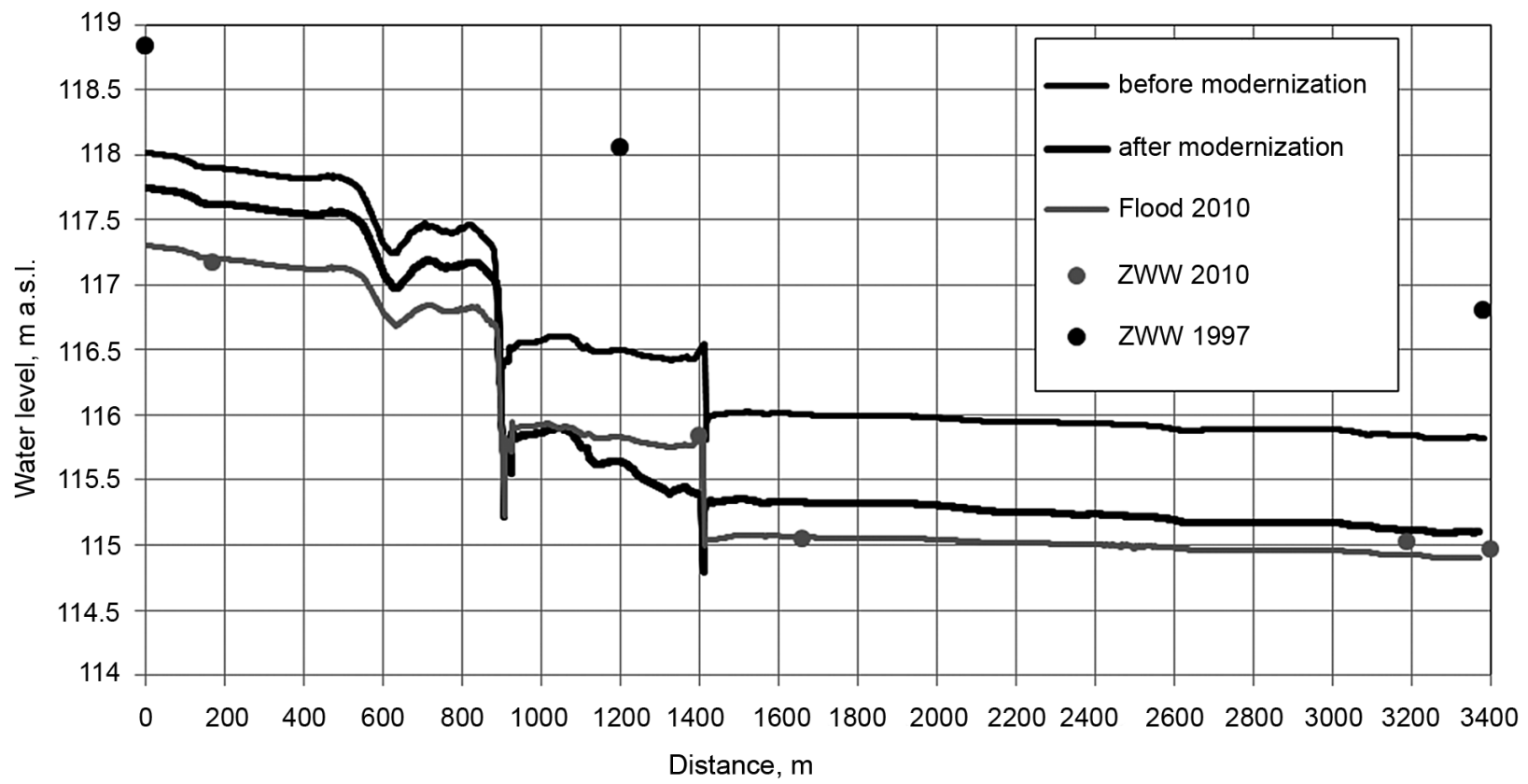

Fig. 5. Water level profile along the Southern Odra, below the Pokoju bridge

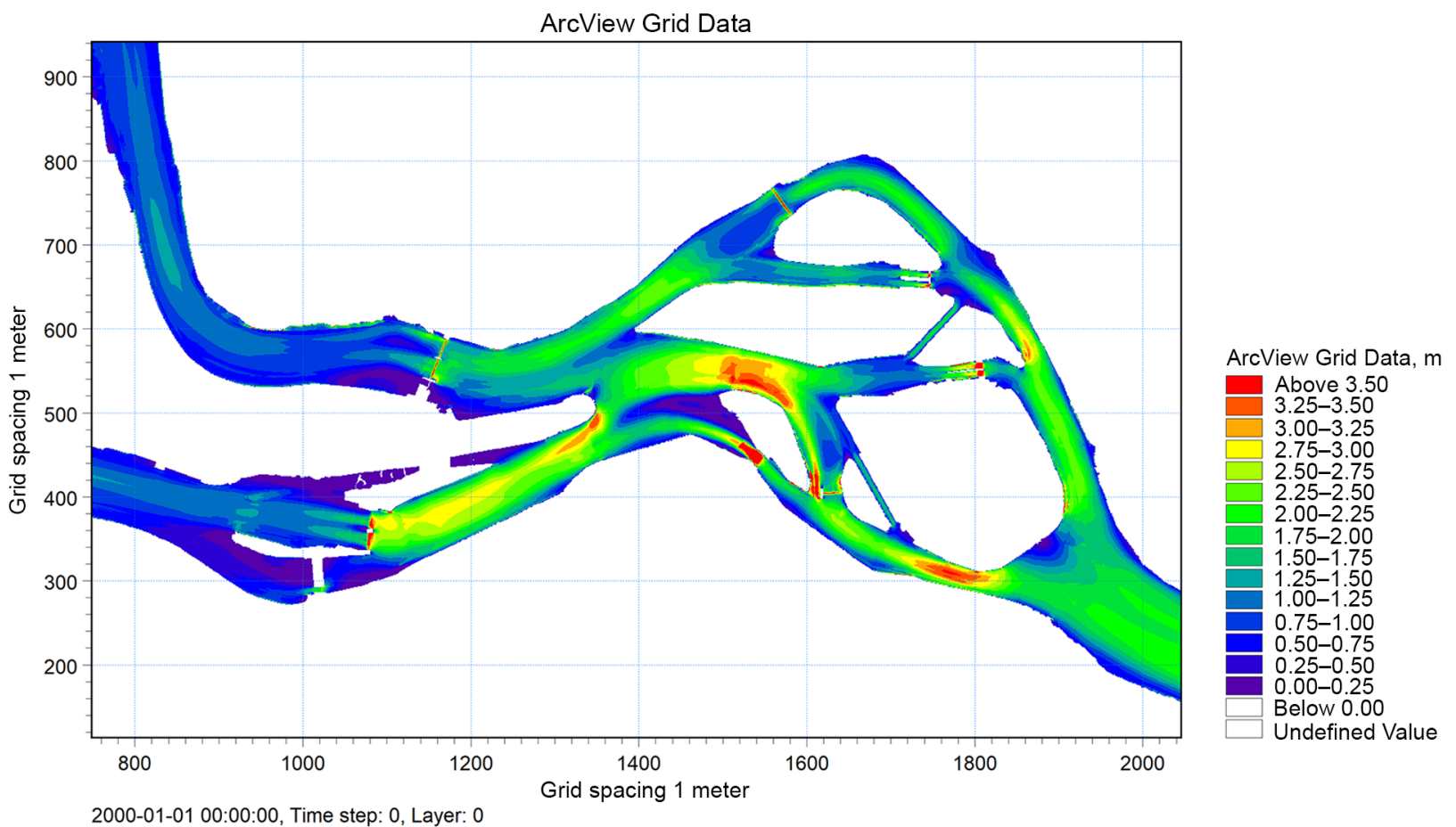

Fig. 6. Depth averaged flow velocities for the design flow $Q_{k}$ 
control water table will be approx. $0.2-0.4 \mathrm{~m}$ above the maximum level for the 2010 flood. More interesting is, however, the comparison with the catastrophic 1997 flood situation, the so-called "Thousand-year water", which caused the flooding of one-third of the city of Wrocław. Water table ordinates for that flood, marked in Fig. 5, are significantly above the so-far discussed and emphasise the catastrophic nature of this phenomenon. Thereupon, an attempt will be made to designate / verify the maximum flow of that event in the $\mathrm{CCH}$.

For this purpose, both the results of calculations and the available measurement data were used. The analysis has been related to the levels at the upper station of the Szczytniki weir (1600 m upstream of the Pokoju bridge) as the most reliable reference when it comes to the ordinates of the water table. On the 12th of July at 10:00 a.m., according to the measurement carried out from the Pokoju bridge, the flow rate was $990 \mathrm{~m}^{3} \cdot \mathrm{s}^{-1}$ (Czaban, 2002). Culmination of the 1997 flood came on the 13th of July between 12:00 a.m and 3:00 a.m. From the moment of measurement to the culmination, the water table ordinate at the upper station of the Szczytniki weir increased by approx. $0.85 \mathrm{~m}\left(\mathrm{H}_{\max } 119.54 \mathrm{~m}\right.$ above sea level). These data and the data from the 2010 flood agree with the simulation results with the 2D model and allow to determine the relationship between the water level ordinate and the flow rate for the Pokoju bridge section (see: Fig. 7). This relationship is almost linear, and this linearity results from the influence of damming at the upper checkdam of the hydrosystem. This dependence also shows that the maximum flow in the $\mathrm{CCH}$ during the July 1997 flood, i.e. with the observed maximum ordinate of about $118.85 \mathrm{~m}$ above sea level, reached approx. $1300 \mathrm{~m}^{3} \cdot \mathrm{s}^{-1}$. This is convergent with the value of $1350 \mathrm{~m}^{3} \cdot \mathrm{s}^{-1}$, the estimate made after the flood (Czaban et al., 1998).

\section{SUMMARY}

For years, the assessment of the hydraulic capacity of the $\mathrm{CCH}$ has been a difficult subject of research that provides an important context for flood protection in the city of Wrocław. The aim of this article was to present this issue in a new perspective using current

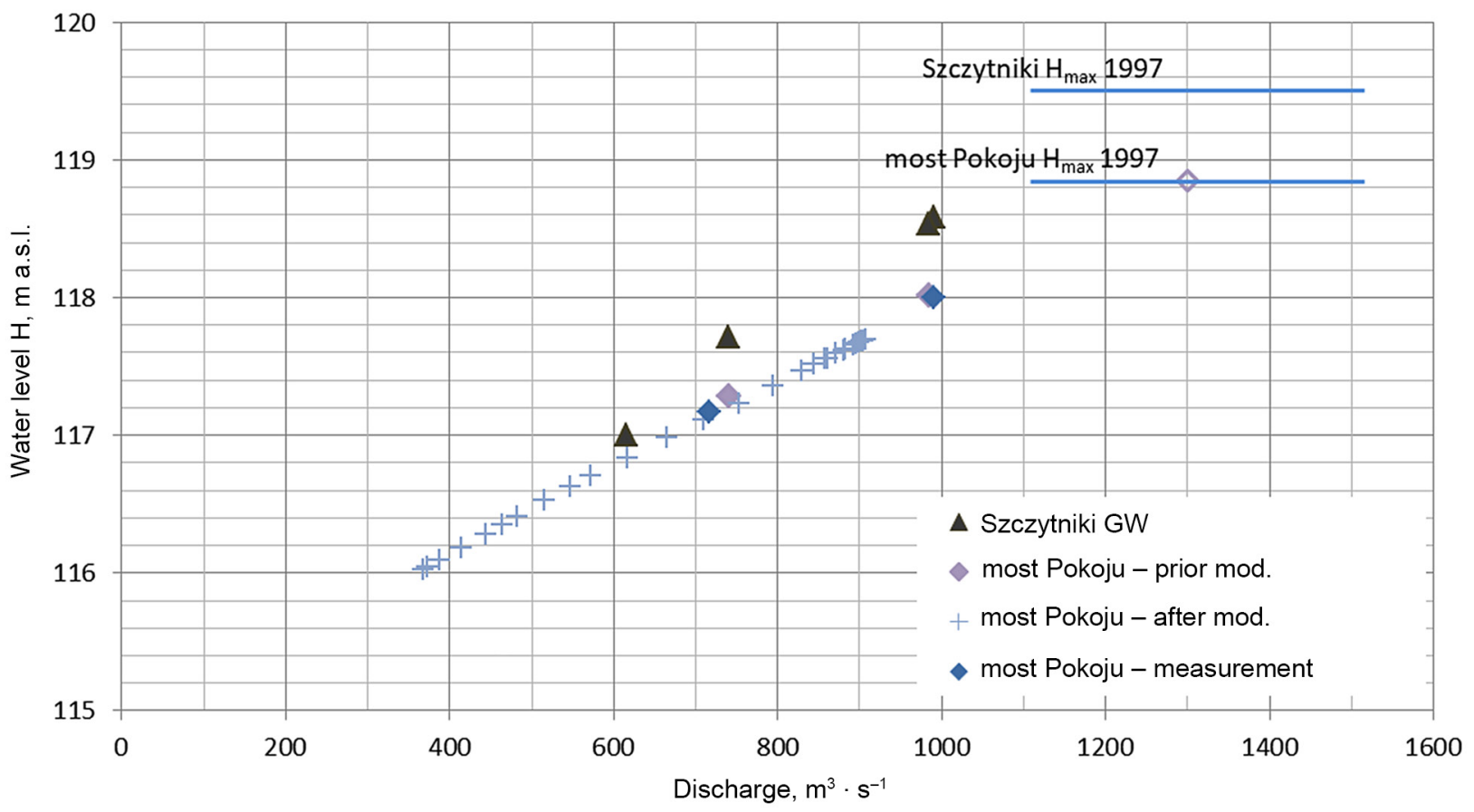

Fig. 7. Water table level - distribution dependence for the section below the Pokoju bridge and above the Szczytniki weir 
research capabilities, in particular the hydrodynamic 2D modelling, and using new topographic, bathymetric and hydrological data. This allows a verification and a better assessment of flood waters flow conditions within the hydraulically complicated $\mathrm{CCH}$, both in terms of reconstructing the conditions for the passage of historical floods as well as forecasting in a hypothetical situation.

Based on the performed simulations, the distribution of water flows in individual channels and their corresponding water table level for the 2010 flood were established, as well as for the control water for the conditions before and after the modernisation of the hydrosystem. These values are $740,984 \mathrm{i} 909 \mathrm{~m}^{3} \cdot \mathrm{s}^{-1}$, respectively. As a result of the modernisation works, the position of the water table will decrease within the range of $0.25-0.7 \mathrm{~m}$ and will be significantly below the design basis, which means that the current hydrosystem capacity is higher than expected. However, a disadvantage was identified, and namely in the fact that the upper checkdam is heavily loaded. In addition, it was determined that the maximum flow in the $\mathrm{CCH}$ during the catastrophic 1997 flood amounted to approximately $1300 \mathrm{~m}^{3} \cdot \mathrm{s}^{-1}$.

\section{REFERENCES}

Banasiak, R., Krzyżanowski, M. (2015). Ocena reżimu morfologicznego i oporów ruchu podczas wezbrań w Odrze Środkowej. Acta Sci. Pol. Formatio Circumiectus 14(2), 25-38.

Banasiak, R. (2017). Dwuwymiarowe modelowanie hydrodynamiczne Wrocławskiego Węzła Wodnego i przejścia powodzi w maju 2010 r. Gospodarka Wodna, 10, 297-302.

Banasiak, R. (2018). Ocena przepustowości Wrocławskiego Węzła Wodnego przed i po modernizacji. Gospodarka Wodna, w druku.

Czaban, S., Czamara, W., Krężel, J., Sobota, J., Urbański, I. (1998). Przepływy we Wrocławskim Węźle Wodnym podczas I wezbrania w lipcu 1997. Zesz. Nauk. AR, 339, Konferencje XXI, 25-33.

Czaban, S., Mokwa, M. (1999). Kształtowanie się modułów przepływu we Wrocławskim Węźle Wodnym. Zesz. Nauk. AR, 363, Konferencja, XXIII, 155-166.

Czaban, S. (2002). Modernizacja Wrocławskiego Węzła Wodnego w świetle doświadczeń z powodzi w $1997 \mathrm{r}$. Zesz. Nauk. AR we Wrocławiu, Konferencje XXV, 437, 79-88.

Hydroprojekt Warszawa, Hydroprojekt Wrocław, Jacobs GIBB, GIBB Polska, 2004. Studium wykonalności dla zbiornika wodnego Racibórz na rzece Odrze i modernizacji Wrocławskiego Węzła Wodnego. Maszynopis.

ISOK (2013) Raport z wykonania map zagrozenia powodziowego i map ryzyka powodziowego http://www.isok. gov.pl/dane/web_articles_files/2783/raport-z-wykonania-map-

Jełowicki, J. (1999). Model symulacyjny przepływu w systemie koryt rzecznych $\mathrm{z}$ zabudowa przeciwpowodziowa. Zesz. Nauk. AR we Wrocławiu, Konferencje XXI, 339, 187-197.

Kudela, H., Szczegielniak, Cz. (1994): Model symulacyjny przejścia wód powodziowych przez hydrowęzeł wrocławski. Raport serii sprawozdania 10/94, Inst. Techn. Cieplnej i Mech. Płynów Politechniki Wrocławskiej.

Parzonka, W., Szczegielniak, Cz. (1972). Ocena skuteczności działania systemu przeciwpowodziowego $\mathrm{m}$. Wrocławia oraz koncepcje jego przebudowy. Gospodarka Wodna 7/72, 255-258.

Radczuk, L., Jełowicki, J., Eljasiewicz, R., Mokwa, M. (1999). Ocena rozdziału wód w hydrowęźle wrocławskim w czasie powodzi 1997 r. Zesz. Nauk. AR we Wrocławiu, Konferencje XXIII, 363, 263-275.

Radczuk, L., Parzonka, W., Eljasiewicz, R., Głowski, R., Jełowicki, J., Kasperek, R. (2002). Hydrauliczna ocena przepustowości Wrocławskiego Węzła Wodnego i doliny Widawy przed i po modernizacji. Zesz. Nauk. AR we Wrocławiu, Konferencje XXXV, 437, 283-294.

Tymiński, T. (2011). Wielkogabarytowy model laboratoryjny Wrocławskiego Węzła Wodnego. Nauka, Przyr., Technol., 5,6, 1-11. 


\section{HYDRODYNAMICZNY MODEL 2D ŚRÓDMIEJSKIEGO WĘZŁA WODNEGO WE WROCŁAWIU I ANALIZA JEGO PRZEPUSTOWOŚCI POWODZIOWEJ}

\section{ABSTRAKT}

\section{Cel pracy}

Analiza przepływu wód powodziowych przez wrocławski Śródmiejski Węzeł Wodny przed i po jego modernizacji.

\section{Materiały i metody}

Wykorzystanie numerycznego dwuwymiarowego modelu hydrodynamicznego MIKE21 oraz narzędzi GIS. Wykorzystanie danych pomiarowych powodzi historycznych.

\section{Wyniki i wnioski}

Przedstawiono wybrane charakterystyki hydrauliczne, w tym rozdział przepływu wód w korytach węzła oraz profile zwierciadła wody dla obydwu wariantów z oceną wpływu inwestycji. Zweryfikowano przepływ maksymalny w Odrze Miejskiej podczas powodzi w 1997 r.

Słowa kluczowe: rzeka Odra, Śródmiejski Węzeł Wodny, dwuwymiarowy model hydrodynamiczny, powódź 